\title{
The phonology of Greek lyric meter ${ }^{1}$
}

\author{
CHRIS GOLSTON \\ California State University, Fresno \\ TOMAS RIAD \\ Stockholm University
}

(Received I6 May 2003; revised I8 June 2004)

The meter of Greek lyric poetry shows great variation within and between lines regarding the shape, number and combinations of basic metrical units. We offer a simplifying analysis in terms of markedness, in which meters are defined by distinctive violations of linguistic constraints controlling rhythm, layering, binarity, and alignment. The constraints that are distinctively violated in meter are low ranked in the phonology of Greek.

\section{INTRODUCTION}

Greek lyric poetry (circa 650-450 BCE) makes use of a remarkably large set of distinct meters. This poses major challenges to linguistic theories of metrics, including: What are the basic units of analysis? How are these basic units defined linguistically? What is the relationship between lyric meter and the Greek language?

We propose the following answers:

- The basic units of Greek lyric meter are dactylic and trochaic.

- Dactylics violate NoClash; Trochaics violate NoLAPSE.

- NoClash and NoLAPSE are ranked low in Greek phonology.

Traditional analyses of lyric meter are based on large units called cola or lengths; these have special names (adonean, pherecratean, hagesichorean, etc.) and fairly idiosyncratic shapes up to nine syllables in length. The first task of this paper is to reduce this plethora of analytical primes to two units that are found elsewhere in Greek meter, one dactylic, the other trochaic. Lyric meters tend to mix what epic and dramatic meters keep separate. In epic a line is dactylic throughout; in dramatic meters it is iambic or trochaic throughout. But in lyric meter a line usually mixes dactylic and trochaic elements.

[I] We would like to gratefully acknowledge financial support from the Birgit och Gad Rausings Stiftelse för Humanistisk Forskning, and also the grant to T. Riad for the project 'Språk och versmetrik' from The Swedish Research Council. We thank the anonymous $J L$ referees for their very useful input, which has helped us to clarify several points in this paper. 
Following Golston \& Riad (2000), we define dactylic units as the smallest units of meter that always contain a stress clash, and trochaic units as the smallest units of meter that always contain a stress lapse (see sections 4.I, 4.2 below for these terms). These basic units of Greek meter are not rhythmic, as is traditionally assumed, but quintessentially arrhythmic, consistently violating the two constraints that enforce rhythmic well-formedness in natural language, NoClash and NoLApse.

Finally, we suggest that NoClASH and NoLAPSE can be violated in meter because they are ranked low in the phonology of Greek. Constant stress clash and constant stress lapse are of course linguistically marked, even in Greek, and we propose that this linguistic markedness is what makes them aesthetically serviceable. Children's meters can be rhythmic in a simplistic way (Burling 1966), but adult meters require more sophistication than dumdi dumdi affords. This sophistication requires marked structures, specifically rhythmically marked structures. Additional sophistication in lyric meter comes from devices like catalexis and extrametricality. Though these are not the central elements of lyric meter, they do serve to differentiate lyric meters from each other.

We rely heavily on a number of scholarly compendia for the generalizations over data, including Dale (1950, I968), Page (1955), Maas (1962), Raven (1962), Snell (1962), Korzeniewski (1968), Halporn, Ostwald \& Rosenmeyer (1980), and West (1982). We refer the interested reader to these works for traditional analyses and for many details we must omit due to the scope of this paper.

After a brief discussion of the relation of meter to language in section 2, we survey the major metrical patterns to be accounted for and reduce them to dactylic and trochaic units using catalexis and extrametricality (section 3). We then formalize our analysis in terms of markedness and relate it to the phonology of Greek (section 4). We end with a discussion of earlier analyses in section 5 , and section 6 is a brief conclusion.

\section{Meter and language}

It is common in metrics to speak of feet, metra, cola, and so on. Following much work in generative metrics we assume that these are homologous to constituents of the prosodic hierarchy used in the phonology of ordinary speech (Hayes 1989). Just as phonology shapes the prosody of words when prosody outranks morphology (McCarthy \& Prince 1993b), it shapes the prosody of sentences when prosody outranks syntax (Golston I998, Golston $\&$ Riad 2000). The unmarked order for normal speech, of course, has morphology above phonology (McCarthy \& Prince 1993b) and syntax above phonology (Golston 1995). Prosodic morphology and poetic meter subvert these rankings for linguistic and artistic reasons, respectively.

Below is a diagram of the prosodic hierarchy with linguistic terms to the right, and (some) metrical terms to the left. 
(I) The prosodic hierarchy

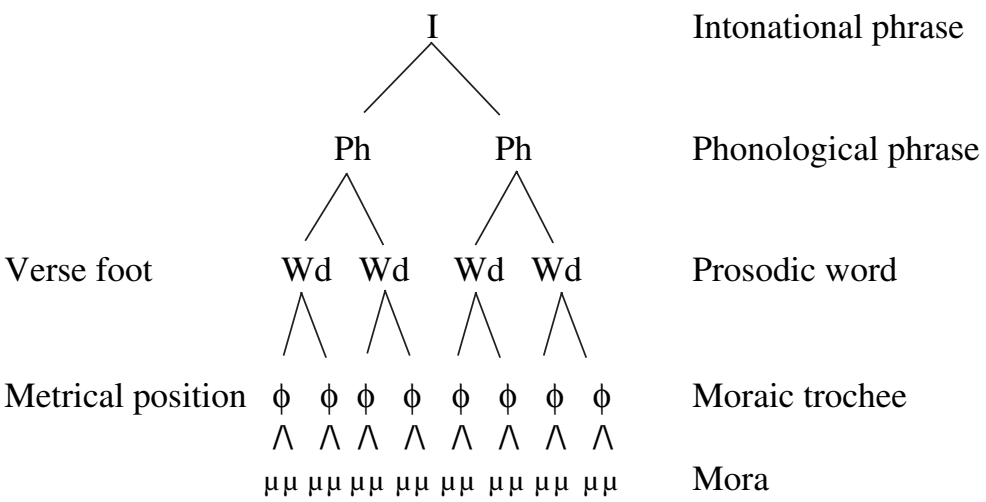

The terms on the right will be familiar from Nespor \& Vogel (I986), Selkirk (1986), Hayes (1989), as well as other work in prosodic phonology, and are determined by alignment constraints that relate prosodic to syntactic structure. The terms on the left are those metrical terms whose correspondence to actual prosodic units does not vary in Greek. Every metrical position in Greek meter is a moraic trochee, usually full (H or LL) and sometimes degenerate (L). Every verse foot in Greek meter is composed of two such metrical positions. For the present purposes, dactylic verse feet are [H.LL] or [H.H]; trochaic feet are [H.L] or [H.H].

Above this level the terminology shifts in ways that we will explore in more detail below. But the basic story is this: a dactylic 'metron' corresponds to a prosodic word (two moraic trochees) and a trochaic 'metron' corresponds to two prosodic words (four moraic trochees), i.e. to a prosodic phrase. For this reason there is no way to equate any level of the prosodic hierarchy to the level of the traditional metron: the dactylic metron (a pair of moraic trochees) is located one layer lower than the trochaic metron (two such pairs). The reason for this seems to be that traditional metrics counts out one 'dactylic metron' for every constituent that always has a stress clash; and it counts out one 'trochaic metron' for every constituent that always has a stress lapse. Typically, then, the metron is the unit which contains a rhythmic event. $^{2}$

We note here that 'in Greek classical verse there appears to be no attempt to achieve agreement between accent and metre in any part of the line in any spoken meter' (Allen 1973: 26I). Although word-accent may play a role in some modern European meters, it plays no role in any classical Greek meters. Greek meter is all about post-lexical patterns of heavy and

[2] For the rhythmically unmarked anapestic meter (Golston \& Riad 2000), tradition counts out a pair of verse feet, hence an eight-mora unit. 
light syllables, not about the accentuation of individual words and never about pitch.

\section{DATA AND PATTERNS}

Lyric poetry comes from all three of the major Greek dialect groups: Dorian (Alcman, Ibycus, Stesichorus, Pindar), Aeolic (Sappho, Alcaeus), and Ionic (Anacreon, Archilochus, Simonides). Since our purposes here are concerned with the typology of meters, we will skip around dialects as needed to cover the basic patterns and build up the generalizations that need to be accounted for. Traditional analysis divides lyric into melic (sung) and non-melic, and we will use that division here for expository purposes. Our goal in this section is just to show that all the patterns are based on similar dactylic and trochaic units. Formal analysis of these units is postponed till section 4 .

\section{I Sung meters}

We begin with a partheneion by the poet Alcman, a song (melos) for a chorus of girls. High tones mark the Greek pitch accent, not to be confused with stress, which falls on moraic trochees as it does in Latin (Allen I987: II6ff.).

(2) Alcman 23.68-76

oúte gár ti porphúras tóssos kóros hoóst' amuúnai neither for some purple such abundance so.that protect

oúte poikílos drákoon paykruúsios, oudè mítra

nor dappled snake all.golden nor headband

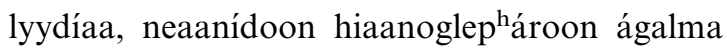

Lydian maidens soft.eyed delight

oudè taì nannóòs kómai, all' oud' arétaa sieideés

nor even Nanno's hair but nor Areta goddess.like

oudè suulakís te kaì kleeesideèra

nor Sylakis and even Kleesidera

oud' es aineesimbrótaas ent ${ }^{\mathrm{h}}$ óisa $\mathrm{p}^{\mathrm{h}}$ aaséìs

nor into Ainesimbrotas' having.entered say

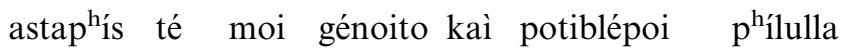

Astaphis and mine be and towards.look Philulla

daamarétaa t' erataá te wiant $\mathrm{t}^{\mathrm{h}} \mathrm{emís}$

Damareta and lovely and Vianthemis

allà hageesik ${ }^{\mathrm{h}}$ óraa me teírei

but Hagesichora me distresses 
'For we have neither such abundance of purple to protect us, nor dappled snake all of gold, nor Lydian headband, the delight of soft-eyed maidens, nor even Nanno's hair, nor Areta like a goddess, nor Sylakis nor Kleesidera nor shall you go to Ainesimbrotas' house and say:

May Astaphis be mine and may Philulla look on me, and Damareta and lovely Vianthemis, but Hagesichora brings me distress.'

As we have said, the linguistic foot used in Greek phonology is the moraic trochee (Allen I973). A full moraic trochee is either a heavy syllable ( $\mathrm{gal}$, daa, doon, etc.) or two lights (te, $\left.t i, p^{h} \dot{u}, k o ́, a\right)$, and a degenerate moraic trochee is a single light. Every metrical position is a moraic trochee in Greek meter and every verse foot is a pair of moraic trochees.

Word-breaks are irrelevant for determining syllable weight within a line; if a consonant-final word is followed by a vowel-initial word the final consonant is parsed as the onset to the initial vowel (cf. French liaison).

(3) Syllabified text

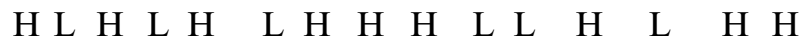
oú.te.gár.ti.por.p ${ }^{\mathrm{h}}$ ú.ras.tós.sos.kó.ro.shoós.ta.muú.nai

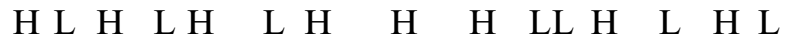
oú.te.poi.kí.los.drá.koon.pan.kruú.si.o.sou.dè.mít.ra

$\begin{array}{lllllllllllll}\text { H } & \text { LH } & \text { LH } & \text { L } & \text { H } & \text { H } & \text { H } & \text { L } & \text { L } & \text { H } & \text { L } & \text { H } & \text { L }\end{array}$ lyy.dí.aa.ne.aa.ní.doo.nhiaa.nog.le.p á.roo.ná.gal.ma

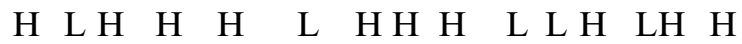
ou.dè.taì.nan.nóòs.kó.mai.al.lou.da.ré.taa.si.ei.deés

H L H L H L H LH L H L ou.dè.suu.la.kís.te.kaì.kle.ee.si.deè.ra

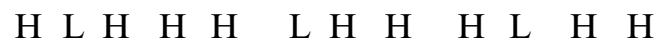
ou.de.sai.nee.sim.bró.taa.sen. $\mathrm{t}^{\mathrm{h}}$ ói.sa. $\mathrm{p}^{\mathrm{h}}$ aa.séìs

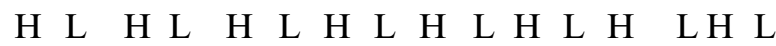
as.ta.p ${ }^{h}$ ís.té.moi.gé.noi.to.kaì.po.tib.lé.poi.phí.lul.la

H L L H L L H L LH L L daa.ma.ré.taa.te.ra.taá.te.wi.an. $\mathrm{t}^{\mathrm{h}}$ e.mí.s

H L L H L L H L H H al.là.ha.gee.si.k $\mathrm{k}^{\mathrm{h}}$.raa.me.teí.rei

This focus on post-lexical syllables rather than lexical syllables is found in all classical Greek, Latin and Sanskrit meters (see e.g. Allen I973: 46-73). 
Patterns appear if we line up correspondences between metrical positions and group them.

(4) Correspondences by line
(H L H L) (H L H H) (H LL)
( $\mathrm{H} \mathrm{L} \mathrm{H} \mathrm{H)}$
(H L H L) (H L H H) (H LL) (H L H L)
(H L H L) (H L H H) (H LL) (H L H L)
$(\mathrm{H} \mathrm{L} \mathrm{H} \mathrm{H})(\mathrm{H} \mathrm{L} \mathrm{H} \mathrm{H})(\mathrm{H} \mathrm{LL}) \quad(\mathrm{H} \mathrm{L} \mathrm{H} \mathrm{H})$
(H L H L) (H L H L) (H L H L)
$(\mathrm{H} \mathrm{L} \mathrm{H} \mathrm{H})(\mathrm{H} \mathrm{L} \mathrm{H} \mathrm{H})(\mathrm{H} \mathrm{L} \mathrm{H} \mathrm{H})$
(H L H L) (H L H L) (H L H L) (H L H L)
(H LL)
(H LL)
(H LL)
(H LL)
(H LL)
(H LL)
(H L H H)

Lines contain three or four constituents of two types, trochaic ('running') and dactylic ('finger-shaped').

The dactylic has the same shape throughout this text, HLL. As we shall see elsewhere, however, it always surfaces as $\mathrm{HH}$ at the end of major constituents.

\section{(5) Dactylic}

( $\mathrm{H} \mathrm{H})$ period-finally

(H LL) elsewhere

The trochaic has two shapes as well, identical except for the last metrical position, which varies over $\mathrm{L}$ and $\mathrm{H}$.

(6) Trochaic

(H L H L) or

( $\mathrm{H} \mathrm{L} \mathrm{H} \mathrm{H)}$

In our short text we find twelve trochaics shaped HLHL and eleven shaped HLHH. Since the difference is not significant, we abbreviate them as HLHo ( $\sigma$ for syllable).

Every trochaic unit contains a case of moraic lapse (HLHo) and every dactylic unit contains a case of clash (HH, HLL), as we shall see in more detail below. Using ' $\mathrm{T}$ ' for trochaic and ' $\mathrm{D}$ ' for dactylic, we can schematize the basic structure of Alcman's poem as follows:

\section{(7) Alcmanic strophe}

$\begin{array}{lllll}\text { structure } & \text { rhythm } & & \\ \text { TTDT } & \text { lapse } & \text { lapse } & \text { clash } & \text { lapse } \\ \text { TTDT } & \text { lapse } & \text { lapse } & \text { clash } & \text { lapse } \\ \text { TTDT } & \text { lapse } & \text { lapse } & \text { clash } & \text { lapse } \\ \text { TTDT } & \text { lapse } & \text { lapse } & \text { clash } & \text { lapse }\end{array}$




$\begin{array}{lllll}\text { TTT } & \text { lapse } & \text { lapse } & \text { lapse } & \\ \text { TTT } & \text { lapse } & \text { lapse } & \text { lapse } & \\ \text { TTTT } & \text { lapse } & \text { lapse } & \text { lapse } & \text { lapse } \\ \text { DDDD } & \text { clash } & \text { clash } & \text { clash } & \text { clash } \\ \text { DDT } & \text { clash } & \text { clash } & \text { lapse } & \end{array}$

The strophe is a mix of trochaic and dactylic units, some in tetrameters (TTDT, TTTT, DDDD), some in trimeters (TTT, DDT). This is the genius of the lyric line. In epic we can speak of dactylic hexameter, where every line has six dactylics (six cases of clash per line); in drama we find three iambics per line (three cases of lapse), or four trochaics (four cases of lapse). But in Alcman's poem some lines have three such units, others four; some lines have just trochaics (lines 5,6,7), others just dactylics (line 8), others a mix (the rest).

The rhythmic profile of the strophe is thus: lapse lapse clash lapse // lapse lapse clash lapse //, etc. The strophe is rhythmically marked by the lapses and clashes; these are not accidental but desiderata for the meter in question. The markedness is thus distinctive (Golston 1996); the patterns of markedness are distinctive for the meter in question and give it its defining metrical qualities (Golston 1998, Golston \& Riad 2000).

Turning now to the major Aeolic poets, we find the same units and rhythmic anomalies rearranged in slightly different ways. The dactylic and trochaic elements remain, and the ways in which they combine remain very similar.

Sappho had her own type of strophe, with two short lines and one long.

(8) Sappho I.I-3

poi.ki.ló. $\mathrm{t}^{\mathrm{h}}$ ron, $\quad$ aa. $\mathrm{t}^{\mathrm{h}}$ á.na.t' ap ${ }^{\mathrm{h}}$.ró.dii.taa

embroidered.throne immortal Aphrodite

páì dí.os do.lóp.lo.ke, lís.so.maí se

child of Zeus sorrow.weaver I.beg you

meé m' á.sai.si meé.t' o.ní.ai.si dám.na, pót.nia, $\mathrm{t}^{\mathrm{h}}$ úù.mon not me with.anguish nor with.distress subdue lady heart

'Immortal Aphrodite of the embroidered throne,

Child of Zeus and weaver of sorrows - I beg you:

Do not subdue me with anguish, or my heart with distress, my lady.'

Each line is made up of 3 or 5 trochaics and dactylics:

(9) (HLH $\sigma)$ (HLL) (HLH $\sigma)$

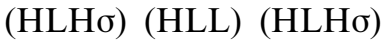

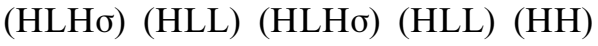

Rhythmically, the strophe is as in (I0). 
(Io) Sapphic strophe

$\begin{array}{ll}\text { TDT } & \text { lapse clash lapse } \\ \text { TDT } & \text { lapse clash lapse } \\ \text { TDTDD lapse clash lapse clash clash }\end{array}$

The arrangement of trochaic and dactylic units differs from the partheneion's, but the basic elements are the same.

Alcaeus wrote many poems using the Sapphic strophe above, but he had his own strophic form as well.

(II) Alcaic strophe

$\begin{array}{llll}\text { a.sun.né.t } & \text { ee.mi tóò.n } & \text { a.né.moon stá.sin } \\ \text { unaccustomed } & \text { I.am of.the winds } & \text { standing }\end{array}$

tò mèn gà.r én. $\mathrm{t}^{\mathrm{h}} \mathrm{en}$ kúù.ma. ku.lín.de.tai

the PRT for thence wave rolls

tò d'én.t $\mathrm{t}^{\mathrm{h}} \mathrm{e} . \mathrm{n}$ ám.mes d'òn tò més.son náà.i $\mathrm{p}^{\mathrm{h}}$ o.reém.me. $\mathrm{t}^{\mathrm{h}} \mathrm{a}$

the PRT thence we and.be the middle ship are.carried

sùn me.laí.nai

with black

'I am unaccustomed to the stance of the winds,

For the wave rolls from one direction

And from another. And we in the middle are carried along with our black ship.'

The Alcaic strophe is built from the same trochaics and dactylics, with a couple of twists.

(I2) $\sigma(\mathrm{HLH \sigma})(\mathrm{HLL}) \quad(\mathrm{HL} \sigma)$

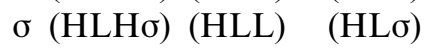

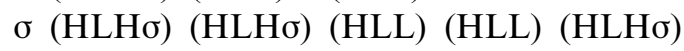

The first twist is the extra unregulated syllable $(\sigma)$ at the beginning of each line, called the Aeolic base because it is so common in Aeolic meters (Hermann I8I6). It is nothing like the 'extrametrical' syllables familiar from English meter, which show up here and there at the edge of a half-line. Every line of an Alcaic strophe begins with an unregulated syllable. The Aeolic base is a necessary part of the line and never marks a position where extra syllables show up now and then. We shall continue to refer to these syllables as 'extrametrical'.

The second little twist is the shortened (catalectic) trochaic at the end of the first two lines, which runs HLo instead of the expected HLHo. Using $\mathrm{T}_{\Lambda}$ for a shortened trochaic we can model this strophe as in (I3). 
(13) Alcaic strophe

$\sigma \mathrm{TDT}_{\Lambda}$ lapse clash lapse

$\sigma \mathrm{TDT}_{\Lambda}$ lapse clash lapse

$\sigma$ TTDDT lapse lapse clash clash lapse

The affinity with the Sapphic strophe is striking once we strip off the initial $\sigma$.

Trochaics need not appear with dactylics mixed in. We find trochaic dimeters as well, as the following fragment from Anacreon illustrates.

(I4) Anacreon 72

póò.le $\mathrm{t}^{\mathrm{h}}$ ree.kí.ee tí deé me

filly Thracian why indeed me

lok.sò.n óm.ma.si b.lé.pou.sa

sideways with.eyes look.at

nee.lé.oos $\mathrm{p}^{\mathrm{h}}$ eú.geis, do.kéìs dé

pitilessly you.flee you.consider and

m' ou.dè.n ei.dé.nai so.phón;

me.not to.be wise

'Thracian filly, why look at me

With sidelong glance,

Why flee me ruthlessly

And think I am unwise?'

The fourth line is catalectic (shortened). The rest of the poem follows the same pattern as these first four lines.

(I5) (HLHo) (HLHo)

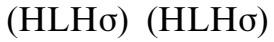

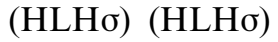

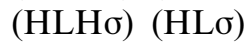

The poem is thus trochaic dimeter with final catalexis every fourth line.

(I6) Anacreon 72

TT lapse lapse

TT lapse lapse

TT lapse lapse

$\mathrm{TT}_{\Lambda}$ lapse lapse

Note that the catalexis does not affect the lapse: catalectic [HLo] still has the same moraic lapse that acatalectic [ㄴHHo] has.

Not all meters are so straightforward. In late antiquity, Anacreon's name was associated with a meter which pushes the envelope of the system. 
(I7) Anacreon II.I-6

á.ge deè phé.r' hee.mì.n óò pái

come indeed bring to.us hey child

ke.lé.been hó.koo.s á.mus.tin

cup so.that in.one.breath

pro.pí.oo, tà mèn dé.k’ en.k $\mathrm{k}^{\mathrm{h} e ́ a s}$

I.may.drink the PRT ten in-pour

hú.da.tos, tà pénte d' oínou

water the five PRT.wine

ku.á. $\mathrm{t}^{\mathrm{h}}$ ous hoos a.nu.bris.toos

ladles so.that not.proudly

a.nà deeuù.te ${ }^{3}$ bas.sa.reé.soo

up again I.will.be.Bassaree

'Hey kid, come bring us

that cup so I can drink it out

in one breath; mix it ten ladles

of water to five of wine

and, without a trace of pride,

I will become a Bassaree.'

The second half of an anacreontic line is a simple trochaic (T). But the first half of the anacreontic and both halves of the fifth line ('ionic dimeter') are not normal trochaics and require some discussion.

(I8) Anacreontic strophe

(LLHL) (HLHo)

(LLHL) (HLHo)

(LLHL) (HLH $\sigma)$

(LLHL) (HLHo)

$(\mathrm{LLHH})(\mathrm{LLH} \sigma)=$ 'ionic dimeter'

(LLHL) (HLHo)

The first half of each anacreontic line begins with a new unit, LLHL, which has an initial LL or 'pyrrhic' foot. This unit has the same lapse (LLHL) as the regular trochaic (HLHo), but at the end of the unit rather than the beginning. We annotate this modified trochaic as $\mathrm{T}_{\mathrm{a}}$ (anacreontic trochaic) for the present. More problematic is the fifth line of the strophe, LLHH LLHo, traditionally referred to as ionic dimeter. Ionic dimeter is problematic for traditional analyses because it contains two arrhythmic verse feet (LL and

[3] The two first syllables of deeuùte are mixed together here to form a single syllable ('crasis'). 
$\mathrm{HH}$ ) that do not show up much in Greek meter. The problem for our analysis is that neither verse foot contains a stress lapse (HL). We annotate this problematic type of trochaic as $T_{i}$ (ionic) and return to it shortly. Setting aside the deviance of $T_{a}$ and $T_{i}$ for the moment, there is a clear pattern to this strophe, and one that is still dominated by stress lapse.

(ig) Anacreontic strophe

$\mathrm{T}_{\mathrm{a}} \mathrm{T}$ lapse lapse

$\mathrm{T}_{\mathrm{a}} \mathrm{T}$ lapse lapse

$\mathrm{T}_{\mathrm{a}} \mathrm{T}$ lapse lapse

$\mathrm{T}_{\mathrm{a}} \mathrm{T}$ lapse lapse

$\mathrm{T}_{\mathrm{i}} \mathrm{T}_{\mathrm{i}}$ ? ? = 'ionic dimeter'

$\mathrm{T}_{\mathrm{a}} \mathrm{T}$ lapse lapse

The ionic dimeter (LLHH LLHo) has traditionally been treated as an anacreontic (LLHL HLHo) with the two middle metrical positions switched (LLHH LLHo). Swapping H and L across metrical positions like this is referred to as 'anaclasis', and the ionic dimeter above is traditionally treated as an 'anaclastic ionic'. Anaclasis is rare in Greek meter and has a skewed distribution, as it never occurs in spoken verse (Halporn et al. I980: 23). We provide a formal treatment of anaclasis below (section 4.5), in which we show that the lapse can be restored, making the whole structure marked by lapse.

\subsection{Iambi, elegi, epodes}

Non-melic lyric poetry comes in three types. Iambi is a cover term for trochaic tetrameter and iambic trimeter, traditionally lumped together because they are so similar metrically. These are both 'stichic' meters that repeat a given pattern every line. Elegi and epodes are not stichic, and lines differ as to internal composition within the same poem, much as we have seen in the various strophes above.

We begin with trochaic tetrameter, which is straightforward.

(20) Archilochus 58

tóìs $\mathrm{t}^{\mathrm{h}}$ e.óìs $\mathrm{t}^{\prime}$ ei. $\mathrm{t}^{\mathrm{h}}$ éi ha.pan.ta pol.lá.kis mè.n ek ka.kóòn the gods and.be.easy all.things often PRT from bad.things

án.dra.s or. $\mathrm{t}^{\mathrm{h}}$ óù.sin me.laí.nee kei.mé.nou.s e.pì $\mathrm{k}^{\mathrm{h}} \cdot \mathrm{t}^{\mathrm{h}} \mathrm{o} \cdot$ ní $^{-}$ men straighten black lying on earth pol.lá.kis d' a.nat.ré.pou.si kaì má.l' éù be.bee.kó.tas often and.they.overturn even very well overpower

hup.tí.ous klií.nou.s' é.pei.ta pol.là gíg.ne.tai ka.ká supine they.lie Then many become bad.things 
kaì bí.ou $\mathrm{k}^{\mathrm{h}}$ reé.mee pla.náà.tai kaì nó.ou pa.reé.o.ros and of.life in.need they.wander and of.mind unharnessed

'All things are easy for the gods. They often raise up from troubles men lying on the black earth.

And they often overpower even those who are doing well

And lay them flat. Then come many bad things

And men wander in need of life but free of sense.'

The meter reduces to four trochaic units per line, the last of which is catalectic.

(2I) Trochaic tetrameter catalectic

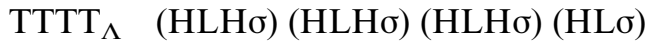

$\mathrm{TTTT}_{\Lambda} \quad(\mathrm{HLH} \sigma)(\mathrm{HLH} \sigma)(\mathrm{HLH} \sigma)(\mathrm{HL} \sigma)$

etc.

Also common in Archilochus is the iambic trimeter, which Archilochus was said in ancient times to have invented (Brown 1997: 44). Despite the name, the trimeter shares the basic metrical make-up with the trochaic tetrameter. ${ }^{4}$

(22) Archilochus fragment $4{ }^{-}-44$

kee.rú.los

kingfisher

pé.trees e.pì p.ro.blée.to.s ap.te.rús.se.to

rock on protruding she.was.flapping

[hee d'] hoós.pe.r au.lóoi brúu.to.n eè $\mathrm{t}^{\mathrm{h}}$ ré.iks a.neèr

she and like through.pipe beer either Thracian man

eè $\mathrm{p}^{\mathrm{h}}$ rùks é.muz.de kúb.da d' éen po.neo.mé.nee

or Phrygian sucked head.down and was working.hard

hee dé hoi sá. $\mathrm{t}^{\mathrm{h}} \mathrm{ee}$

... the and his prick

hoós.t' ó.nou pri.ee.né.oos

like donkey Prienian

keé.loo.no.s ep.leé.muu.re.n ot.ru.geep ágou

stud swelled grain-eating

pol.lòs d' $a p^{\text {h }}$.rò.s éen pe.rì s.tó.ma

... much and foam was around mouth

[4] For instance, word breaks are avoided (bridges) and preferred (caesurae) in the same places in the two meters. 
'Up and down she bounced

like a kingfisher flapping on a jutting rock.

Like a Thracian or Phrygian drinking beer through a tube

She sucked, stooped down, engaged too from behind.

And his dong ... flooded over like a Prienian

stall-fed donkey's ...

... foam all around her mouth ...' (tr. West 1993: 6)

The meter here is simple, but there are two possible analyses of it, one iambic and one trochaic. The iambic analysis starts crisply at the left, incorporating the Aeolic base ( $\sigma)$ into the line directly.

\section{(23) Iambic analysis}
I I I $(\sigma \mathrm{HLH})(\sigma \mathrm{HLH})(\sigma \mathrm{HL} \sigma)$
I I I ( $\sigma \mathrm{HLH})(\sigma \mathrm{HLH})(\sigma \mathrm{HL} \sigma)$
etc.

The second analysis, which we will follow here, separates out the Aeolic base and has the final trochaic unit catalectic.

(24) Trochaic analysis
$\sigma \mathrm{TTT}_{\Lambda} \quad \sigma(\mathrm{HLH \sigma})(\mathrm{HLH} \sigma)(\mathrm{HL} \sigma)$
$\sigma \mathrm{TTT}_{\Lambda} \quad \sigma(\mathrm{HLH \sigma})(\mathrm{HLH} \sigma)(\mathrm{HL} \sigma)$
etc.

From our standpoint the analyses are very similar, as each has the same amount of lapses, one for each HL string. The traditional analysis is iambic, but the iambic/trochaic distinction is very marginal in traditional metrics. All major handbooks agree that iambic and trochaic meters are at base very similar and are easily interchanged even in the same text (see e.g. West 1982: 40). As Raven puts it,

In general, the two types of verse run so much after one pattern that it is sometimes helpful to conceive of both (as the poets unquestionably did) merely as alternations of long elements with short/anceps

$$
\ldots \cup-\underline{\cup}-\cup-\underline{\cup}-\cup \ldots
$$

from which segments can be cut, the use of the terms 'iambic' and 'trochaic' depending only on whether a segment begins with anceps or long. ... For there are features common to both, and obviously identical, whose nature is obscured if we speak too rigidly in terms of iambic or trochaic 'feet'. Raven (1962: 27)

[5] Farnell (I89I: 65) expresses the same insight:

Trochaic may be regarded as the predominating metre throughout Greek lyric poetry, and indeed Greek poetry in general, for it not only prevails in trochaic lines proper, but 
This similarity must have an explanation. We propose that persistent stress lapse is what unites iambic and trochaic meter in Greek. They are felt to be the same rhythmically because they violate the same rhythmic constraint, NoLAPSE, just in different ways: iambic [oH.LH], trochaic [HL.Ho], anacreontic [LL.HL]. This is what sets them apart from dactylic and spondaic meters, which never have lapse and always have clash, and from anapestic meters, which are marked by eurhythmy (Golston \& Riad 2000).

Turning now to elegy, the elegiac couplet consists of a line of dactylic hexameter plus a line of dactylic 'pentameter' so-called, actually two small lines. A poem consists of one or more of these three-line 'couplets'.

(25) Archilochus, Elegy 2

en do.rì mén moi máàz.da me.mag.mé.nee, en do.rì d'óì.nos

at spear PRT my barleycake kneaded at spear and.wine

is.ma.ri.kós pií.noo

Ismarian I.drink

en do.rì kek.li.mé.nos

in spear leaning

'By my spear is my kneaded barley cake, and by my spear is my Ismarian wine. I drink it, reclining on the spear.'

As is the case with dactylics in epic meter, dactylics in an elegiac couplet may be either HLL or HH, though only HH appears line-finally. The short lines end in a single $\mathrm{H}$, which we take to be a final extrametrical position akin to the Aeolic base. (The long, final vowel of memagménee shortens before another vowel.)

(26) (HLL) (HH) (HLL) (HLL) (HLL) (HH)

(HLL) (HH) $\mathrm{H}$

(HLL) (HLL) H

The pattern is fairly simple, a line of dactylic hexameter followed by two hemiepes (the traditional term), each a dactylic dimeter with a final extrametrical syllable.

(27) Elegiac couplet

DDDDDD

DD $\sigma$

DD $\sigma$

gives the character to logaoedics, and even to iambic senarii, or trimeters, which are nothing but trochaic feet with anacrusis. 
Rhythmically, this is just a succession of clashes, with an extrametrical syllable buffering the end of the second and third lines.

(28) clash clash clash clash clash clash

clash clash $\sigma$

clash clash $\sigma$

Final extrametricality like this is expected given the initial extrametricality of the Aeolic base, since initial extrametricality is less marked than final extrametricality both in meter (Burling 1966) and in phonology (Kiparsky I99I, Jacobs I994, Kager I995). ${ }^{6}$

The many Archilochean epodes that remain give us a look into an elaborate system. West (I989) groups the epodes of Archilochus into the following types, where we use $\phi$ as a variable over $\mathrm{H}$ and LL (a moraic trochee). The middle column provides our analysis, which treats all of the types as dactylic and/or trochaic.

(29) Types of epode in Archilochus ${ }^{7}$

\begin{tabular}{|c|c|c|}
\hline scheme (West I989) & our analysis & epodes \\
\hline $\begin{array}{llllllll}\sigma & \mathrm{H} & \phi & \mathrm{H} & \mathrm{L} & \mathrm{L} & \mathrm{H} & \sigma \\
\mathrm{H} & \mathrm{L} & \phi & \mathrm{L} & \mathrm{H} & \sigma & & \end{array}$ & $\begin{array}{l}\sigma \text { DDD } \\
\text { TD }\end{array}$ & I68-I7I \\
\hline $\begin{array}{llllllllllll}\sigma & H & L & H & \sigma & H & L & H & \sigma & H & L & H \\
\sigma & H & L & H & \sigma & H & L & H & & & & \end{array}$ & $\begin{array}{l}\sigma \mathrm{TTT}_{\Lambda} \\
\sigma \mathrm{TT}_{\Lambda}\end{array}$ & $\mathrm{I} 72-\mathrm{I} 8 \mathrm{I}$ \\
\hline $\begin{array}{llllllllllll}\sigma & H & L & H & \sigma & H & L & H & \sigma & H & L & H \\
H & L & L & H & L & L & H & & & & & \end{array}$ & $\begin{aligned} \sigma & \mathrm{TTT}_{\Lambda} \\
& \mathrm{DD} \sigma\end{aligned}$ & I82-I87 \\
\hline 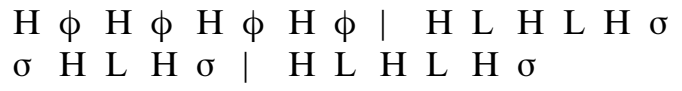 & $\begin{array}{l}\text { DDDDTD } \\
\sigma \text { TTD }\end{array}$ & \\
\hline $\begin{array}{lllllllllllllll}\mathrm{H} & \phi & \mathrm{H} & \phi & \mathrm{H} & \phi & \mathrm{H} & \phi & \mathrm{H} & \mathrm{L} & \mathrm{L} & \mathrm{H} & \sigma \\
\sigma & \mathrm{H} & \mathrm{L} & \mathrm{H} & \sigma & \mathrm{H} & \mathrm{L} & \mathrm{H} & & & & & \end{array}$ & $\begin{array}{l}\text { DDDDDD } \\
\sigma \mathrm{TT}_{\Lambda}\end{array}$ & I93-I94 \\
\hline $\begin{array}{lllllllllllllll}\mathrm{H} & \phi & \mathrm{H} & \phi & \mathrm{H} & \phi & \mathrm{H} & \phi & \mathrm{H} & \mathrm{L} & \mathrm{L} & \mathrm{H} & \sigma \\
\mathrm{H} & \phi & \mathrm{H} & \phi & \mathrm{H} & \mathrm{L} & \mathrm{L} & \mathrm{H} & \sigma & & & & \end{array}$ & $\begin{array}{l}\text { DDDDDD } \\
\text { DDDD }\end{array}$ & I95 \\
\hline $\begin{array}{llllllllllll}\sigma & \mathrm{H} & \mathrm{L} & \mathrm{H} & \sigma & \mathrm{H} & \mathrm{L} & \mathrm{H} & \sigma & \mathrm{H} & \mathrm{L} & \sigma \\
\mathrm{H} & \mathrm{L} & \mathrm{L} & \mathrm{H} & \mathrm{L} & \mathrm{L} & \mathrm{H} & & & & & \\
\sigma & \mathrm{H} & \mathrm{L} & \mathrm{H} & \sigma & \mathrm{H} & \mathrm{L} & \sigma & & & & \end{array}$ & $\begin{aligned} \sigma & \mathrm{TTT}_{\Lambda} \\
& \mathrm{DD} \\
\sigma & \mathrm{TT}_{\Lambda}\end{aligned}$ & I96-I96a \\
\hline
\end{tabular}

These types differ in four ways: catalexis $(\Lambda)$, extrametricality $(\sigma)$, line length, and whether the units are dactylic, trochaic or mixed.

[6] Our theory prohibits us from treating the final $\sigma$ as a catalectic HH. We can have no D without stress clash, so a catalectic dactyl $\left(D_{\Lambda}\right)$ is not a possible entity. The fact that these syllables are line final means that they are realized as $\mathrm{H}$, as all line-final syllables are in Greek.

[7] There are two additional types attributed to Archilochus, but there are no extant texts from Archilochus to support them (West 1989: 77b-78). 
(30) Dactylic and trochaic elements in Archilochus

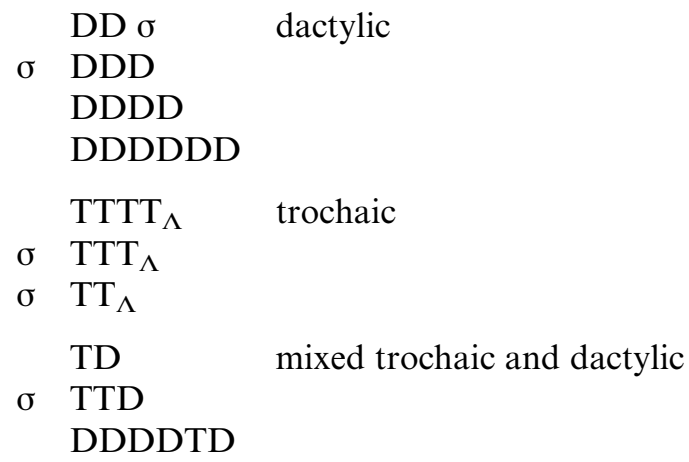

It is thus possible to analyze all of Archilochus' (extant) epodes using elements of analysis that are common elsewhere in lyric meter.

Hipponax (mid-6th century) is said to have invented the choliamb, or 'limping iamb'. A limping iambic line ends in HHo rather than HLo, the expected catalectic trochaic.

(3I) Hipponax Fr. I (West I989: IIo) ${ }^{8}$

óò klaz.do.mé.ni.oi, boú.pa.los ka.ték.tei.nen

Oh Clasdemonians Bupalus has.killed

'Oh Clasdemonians, Bupalus has killed off ...'

The meter is something like (32), or so we will argue.

(32) $\sigma(\mathrm{HLH} \sigma)(\mathrm{HLH} \sigma)(\mathrm{HH}) \sigma$

(The second $\mathrm{H}$ above is realized as two light syllables, mé.ni, in the text.) After the initial extrametrical position, the first two units are straightforwardly trochaic, but the third is not, as noticed long ago by the Greek grammarian Hephaestion.

Worth mentioning among the acatalectic meters is the one called 'lame', which some say was named by Hipponax, others by Ananius. It differs from the regular [iambic] meter, insofar as that meter has as its last foot an iamb or a pyrrhic because of the indifferent (anceps) syllable, but this meter has either a spondee or a trochee. (Hephaestion, Enchiridion 5.4)

Rather than final HLHo, we find HHo, the 'limping' part of the choliamb, which we analyze as a dactyl (because of the stress clash) and a final extrametrical syllable.

[8] The first metron exhibits so-called resolution (marked by underscore). 


\section{(33)}

\section{Choliamb \\ $\sigma$ TTD $\sigma$}

This is a somewhat unlikely structure, but it seems to have struck the ancient Greek ear as unlikely ('limping') as well. ${ }^{9}$ A similar line type is found in the limping tetrameter or 'scazon'.

(34) Hipponax Fr. I2I (West 1989: I56)

am. $\mathrm{p}^{\mathrm{h}} \mathrm{i}$ dék.si.os gà.r ei.mi k'ouk ${ }^{\mathrm{h}}$ ha.mar.tá.noo kóp.toon around right for I.am and.not I.miss striking

'For I am ready and do not miss my strike.'

This is just like the limping trimeter but without the initial extrametrical syllable and with one more trochaic unit.

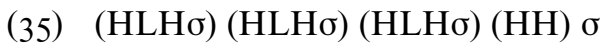

The scazon thus reduces to three trochaics, a dactylic, and a final extrametrical syllable.

(36) Scazon

TTTD $\sigma$

Limping meters are metrical outliers in the system of Greek lyric meter, but we must analyze them nonetheless. Our analysis of them is not elegant, but it reduces these problematic and marginal meters to elements that are recognizable and widely attested elsewhere.

\subsection{Aeolic cola}

The metrical tradition among Greek lyric poets is richer than what we have seen so far, in the same way that the epodes of Archilochus provide a richer set of line types than we find in the Sapphic or Alcaic strophes. West (1982: 30 f.) provides the following list of cola (large metrical units) used by archaic poets, especially Aeolic poets like Sappho and Alcaeus.

(37) Major Aeolic cola (after West 1982: 3of.)

adonean

anacreontic

aristophanean

dodrans

glyconic

hagesichorean
H L L H o

L L H L H L H $\sigma$ H L L H L H o

$\mathrm{H} \mathrm{L} \mathrm{L} \mathrm{H} \mathrm{L} \sigma$

$\sigma \sigma \mathrm{H} \mathrm{L} \mathrm{L} \mathrm{H} \mathrm{L} \sigma$

$\sigma \mathrm{H} \mathrm{L} \mathrm{L} \mathrm{H} \mathrm{L} \mathrm{H} \sigma$

[9] We give here the most surface-true structure, but note that the limping part could also be thought of as a trochaic metron with the internal L syncopated: $\mathrm{H}(\mathrm{L}) \mathrm{H} \sigma$. 


hipponactean
iambic dimeter catalectic
iambic dimeter
ionic dimeter
ithyphallic
lekythion
penthemimer
pherecratean
reizianum
telesillean
trochaic dimeter

hipponactean

$\sigma \sigma \mathrm{H} \mathrm{L} \mathrm{L} \mathrm{H} \mathrm{L} \mathrm{H} \sigma$

$\sigma \mathrm{H} \mathrm{L} \mathrm{H} \sigma \mathrm{H} \sigma$

$\sigma \mathrm{H} \mathrm{L} \mathrm{H} \sigma \mathrm{H} \mathrm{L} \sigma$

L L H H L L H $\sigma$

$\mathrm{H} \mathrm{LH} \sigma \mathrm{H} \sigma$

$\mathrm{H} \mathrm{L} \mathrm{H} \sigma \mathrm{H} \mathrm{L} \sigma$

$\sigma \mathrm{H} \mathrm{LH} \sigma$

$\sigma \sigma \mathrm{H} \mathrm{L} \mathrm{L} \mathrm{H} \sigma$

$\sigma \mathrm{H} \mathrm{L} \mathrm{L} \mathrm{H} \sigma$

$\sigma \mathrm{H} \mathrm{L} \mathrm{L} \mathrm{H} \mathrm{L} \sigma$

$\mathrm{H} \mathrm{L} \mathrm{H} \sigma \mathrm{H} \mathrm{L} \mathrm{H} \sigma$

Classicists know that these terms and categories are not fully satisfactory (Raven I962: 72, West I982: 3I) and suspect that smaller, more familiar units are lurking behind these cola, but no reduction has ever been published to our knowledge. The idea that these types contain more familiar chunks dates back at least to Hephaestion.

In the so-called Aeolic (dactylic) lines, the first foot is always disyllabic, but otherwise indeterminate. It may be a spondee, an iamb, a trochee or a pyrrhic. The middle feet are always dactyls, and the last foot is either a dactyl or a cretic.

(quoted in Davison I968: I3I; emphasis ours)

If we pull out the dactylic elements (HLL) and the trochaic elements (HLHo), it is possible to reduce almost all of the cola above to collocations of simpler and by now familiar units.

We begin with a set of three dimeters that are purely dactylic: the adonean, reizianum and pherecratean.

(38) Dactylic dimeters

$\begin{array}{lrrrr}\text { adonean } & & \text { HLL.H } \sigma & & \text { DD } \\ \text { reizianum } & \sigma & \text { HLL.H } \sigma & \sigma & \text { DD } \\ \text { pherecratean } & \sigma \sigma & \text { HLL.H } \sigma & \sigma \sigma & \text { DD }\end{array}$

On the left are the traditional names for the lengths; in the middle our analysis in terms of Aeolic base and dactylic metra; on the right our shorthand notation. The basic dimeter here we take to be the adonean, a simple concatenation of two dactylics with anceps at the end. Reizianum has the same DD structure with an initial extrametrical syllable, its Aeolic base. Pherecratean is identical to reizianum except that the Aeolic base contains two syllables rather than one. ${ }^{10}$

This same three-way pattern is found in the next two sets of dimeters as well. The first of these contains mixed dimeters consisting of a dactylic (HLL) and a trochaic metron (HLHo).

[Io] The realization of the two syllables in the Aeolic base as L L is uncommon (West I982: 30). 
(39)

Dactylic-trochaic dimeters

$\begin{array}{lrr}\text { aristophanean } & \text { HLL.HLH } & \text { DT } \\ \text { hagesichorean } & \sigma \text { HLL.HLH } & \sigma \text { DT } \\ \text { hipponactean } & \sigma \sigma \text { HLL.HLH } \sigma & \sigma \sigma \text { DT }\end{array}$

The aristophanean dimeter is basic here, a straightforward mix of the two metra seen in the strophes of Alcman, Sappho and the other poets above. The hagesichorean has an extrametrical syllable and the hipponactean has two.

The final set of three dimeters consists of a dactylic followed by the catalectic trochaic metron (HLo) discussed above for Archilochus, Alcaeus and Anacreon.

(40) Trochaic-dactylic dimeters (catalectic)

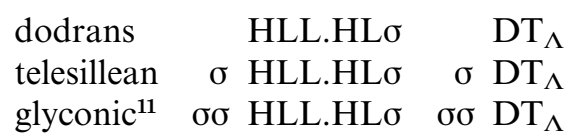

Again, we see a basic pattern that mixes dactylics and catalectic trochaics (dodrans) and expansions on this pattern that add a single (telesillean) or double (glyconic) extrametrical syllable in the Aeolic base.

The nine dimeters just discussed all begin with dactylics and fall into three sets of three. When we turn to cola that begin trochaically, we find another set of nine, but with catalexis playing a more prominent role than extrametricality. We begin again with the lines of pure trochaics.

(4I) Trochaic dimeter

\begin{tabular}{|c|c|}
\hline eter & HLH $\sigma . H L H \sigma$ \\
\hline lekythion & 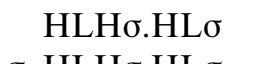 \\
\hline
\end{tabular}

An iambic analysis of the iambic dimeter is also possible, of course, but we will not pursue it here; as we have seen, the distinction between trochaic and iambic in Greek meter is weak and this meter has the same number of lapses no matter which way we analyze it.

Next we have the anacreontic and its anaclastic counterpart the ionic dimeter.

[II] Davison (I968: I33f.) argues that 'Sappho and Alcaeus knew two ways of scanning a Glyconic. Sometimes they scanned it as a dimeter, i.e. antispast or trochaic dipody followed by iambic dipody, and sometimes as a trimeter, i.e. spondee, dactyl, dactyl.' The first scansion is odd in that it would make the line simultaneously trochaic and iambic. The second scansion is less troubling, except for the fact that it still requires treating HLo as a line-final dactyl. Elsewhere in Greek meter a line-final dactyl is always Hб. 
So far we hope to have shown that most Greek lyric meters can be reduced to a small number of primitives, all of which are found elsewhere in Greek epic and dramatic meter. But we have given more descriptions than explanations, so we turn now to a formal analysis of the elements we have used.

\section{Meter and markedness}

We have made use of five traditional notions - dactylics, trochaics, extrametricality, catalexis, and quantity metathesis (anaclasis) - to pull out the basic patterns of Greek lyric meter. In this section we go a step further and analyze these notions in terms of phonological markedness, in an attempt to better understand the patterns we have found.

A driving force in phonology since Jakobson has been the notion of markedness, in typology, in children's language, in corpora, and so on. Here we show that dactylics, trochaics, extrametricality, catalexis, and quantity metathesis violate basic principles of phonology. To encode this we use markedness constraints from Optimality Theory (Prince \& Smolensky I993, McCarthy \& Prince 1993a, b, I995). Specifically, we adopt the idea that markedness can be distinctive (Golston 1996) and that meters can be defined by the constraints they violate (Golston \& Riad 2000).

Crosslinguistically, meter generally uses rhythmic, binary patterns. In the unmarked case we have a symmetrical number of metrical positions (typically eight) and a rhythmic pattern (dumdi dumdi) through the line, which is free of clash and lapse (Burling 1966). If a metrical tradition has a single metrical type, it is usually symmetrical and rhythmic. But if a metrical tradition has several metrical types, not all of them can be equally symmetrical and equally rhythmic. The less symmetrical and less rhythmic types must then be phonologically marked and we can model this markedness by constraint violation. Crucially, the violation is distinctive, i.e. it differentiates one meter from another.

\section{I Clash}

Dactylics are traditionally seen as rhythmic, such that HLL is rhythmically (x..) and HH is (x.). Greek phonology used moraic trochees (Allen I973; Golston 1989, I99I; Noyer 1997), so this traditional characterization cannot be correct. Rather, every $\mathrm{H}$ is prominent, as is the first $\mathrm{L}$ of every $\mathrm{LL}$, so that HLL is (xx.) and HH is (xx). Thus, every dactylic, whether HLL or HH, contains stress clash and violates the following constraint against it (Selkirk I984, Nespor \& Vogel I989).

(46) NoClash 'Stressed syllables are not adjacent.'

Aggressive violation of this constraint is what distinguishes HLL from other combinations of syllables, except of course for the spondee (HH), with which 
HLL alternates in Greek meter. Indeed, if we look at all the traditional verse feet posited for Greek meter, we see that only two of them, HLL and HH, violate NoClash. Below we pair H, L and LL in all nine possible ways and provide traditional terms for each pairing.

Dactyls are verse feet with clash

\begin{tabular}{|cc||c|}
\hline & & NOCLASH \\
\hline \hline H.H & (xx) & D \\
\hline H.L & (x.) & \\
\hline H.LL & (xx.) & D \\
\hline L.H & (.x) & \\
\hline L.L & (x.) & \\
\hline L.LL & (.x.) & \\
\hline LL.H & (x.x) & \\
\hline LL.L & (x..) & \\
\hline LL.LL & (x.x.) & \\
\hline
\end{tabular}

traditional term
spondee
trochee
dactyl
iamb
pyrrhic
tribrach
anapest
tribrach
proceleusmatic

The two verse feet that violate NoClash are exactly those that we find in dactylic meters. Since the violation of NoClash is what makes a verse foot a dactylic we have written in ' $\mathrm{D}$ ' instead of ' $*$ ' to mark the distinctive violation. The markedness is intentional (not accidental) since the violation of NoClash is what defines dactylic meter.

\section{(48) Dactylic $={ }_{\text {def }}$ violation of NoClasH}

Stress clash is the rhythmic event that one finds six of in dactylic hexameter: every line of the Iliad and Odyssey has exactly six stress clashes and that, we claim, is what makes it hexameter.

A question we must pose for lyric meter is why we never get $\mathrm{HH}$ for a dactylic line-initially or line-medially, as we do in dactylic hexameter. Let us assume that constraint violation is minimal in meter, as it is in grammar (Prince \& Smolensky 1993). If so, a strict line of dactylic meter should violate NoCLASH once per dactylic, but no more. But consider how a pair of two HLLs fares in terms of stress clash compared to a pair of two HHs.

\section{(49) Pairs of dactylics}

$\mathrm{x} \mathrm{x}$. x x . clash clash

(HLL)(HLL)

$\mathrm{x} \times \mathrm{x}$ x clash clash clash

$(\mathrm{HH})(\mathrm{HH})$ 
The first pair above (HLL.HLL) has two instances of clash, one per dactylic, and no more. The second pair has three instances of clash, one per dactylic and one more, across the two dactylic units. We can put this in a constraint tableau and annotate the intentional violations of NoCLASH as ' $D$ ' (the ones that we want) and additional violations of NoClash as '*' (the superfluous ones that we do not want).

(50) The optimal dactylic

\begin{tabular}{|c|c|}
\hline & NoClash \\
\hline 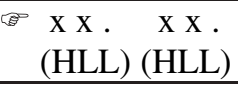 & D D \\
\hline $\begin{array}{cc}\text { x x } & \text { x x } \\
(\mathrm{HH}) & (\mathrm{HH})\end{array}$ & D D *! \\
\hline $\begin{array}{cc}\text { x x } & \text { x x . } \\
\text { (HH) } & \text { (HLL) }\end{array}$ & D D *! \\
\hline
\end{tabular}

Hence HLLHLL makes for a rhythmically better pair than HHHH or HHHLL. All we need to say about lyric meter is that the dactyls are more precise than they are in epic: lyric uses only the best strings of dactylics, while epic uses any strings of dactylics.

The tables turn at the end of the line, where the last metrical position is uniformly treated as $\mathrm{H}$, forcing something that would be HLL to be HH. The best dactylic generally is HLL, but the best line-final dactylic is HH.

(5I) The optimal dactylic, line-finally

\begin{tabular}{|c|c|c|}
\hline & FINALLENGTH & NOCLASH \\
\hline $\begin{array}{cc}\mathrm{x} \times \mathrm{x} & \mathrm{x} \mathrm{x} \\
(\mathrm{HLL}) & (\mathrm{HH})\end{array}$ & & D D \\
\hline $\begin{array}{c}\text { x x . } \quad \text { x x . } \\
(\text { HLL) (HLL) }\end{array}$ & *! & D D \\
\hline $\begin{array}{cc}\text { x X . } & \text { X . X } \\
\text { (HLL) } & (\mathrm{HLH})\end{array}$ & & $\mathrm{D}<\mathrm{D}>$ ! \\
\hline $\begin{array}{cc}\text { x x } & \text { x x } \\
(\mathrm{HH}) & (\mathrm{HH})\end{array}$ & & D D *! \\
\hline
\end{tabular}

The first candidate above has final lengthening and the requisite violations of NoClash ('D'), one for each dactylic unit. The second has no phrase-final lengthening (as it ends in L) and thus loses out to the first. The third has final lengthening of only the last syllable (rather than the last metrical position) and thus gets three metrical positions in the final foot. This prevents the final stress clash, taking away one of the desired violations of NoClash from occurring $(<\mathrm{D}>)$; this candidate is more rhythmic than dactylic meter 
should be and thus loses to the first candidate because it has too little clash. The fourth candidate has final lengthening as well as the desired stress clashes, but it has additional stress clash across the verse feet as well ( $\mathrm{xx} \mathrm{xx})$; it is thus less rhythmic than dactylic meter should be and loses out to the first candidate because it has too much clash.

The difference between lyric and epic meter concerning $\mathrm{HH}$ within the line thus reduces to how carefully the meter respects NoClash. ${ }^{12}$ Lyric meter is exacting and rules out any clashes past the required number. Epic meter, however, allows additional stress clashes across verse feet. In Greek epic the proportion is about $60 / 40$ for HLL and $\mathrm{HH}$, respectively.

We assume that clash can be used as a device in Greek meter because it is ranked so low in the phonology of Greek. Greek has no processes for resolving clash and freely tolerates adjacent heavy syllables.

(52) Clash

$$
\begin{aligned}
& \mathrm{H} \mathrm{H} \\
& \text { hip.pou 'horse (gen)' } \\
& \text { rhii.peé 'force (nom)' } \\
& \mathrm{H} \quad \mathrm{H} \quad \mathrm{H} \\
& \text { luú.oo.men 'we loosen (subj)' } \\
& \text { luú.oi.men 'we loosen (opt)' }
\end{aligned}
$$

We suggest that stress clash was serviceable in Greek meter because it was tolerated in Greek speech. Similar facts obtain for Latin, which also made use of stress clash in dactylic meter (e.g. Virgil's Aeneid) and also tolerated it in speech.

In many languages, however, clash is studiously avoided through stress reduction or stress retraction. We expect the meters of such languages to avoid clash as well and thus do not expect to find Greek-type dactylic meter there. In Dutch and English, for example, we find clash operative in morphological formations that put a stressed suffix on a stem with final stress. In words like expláin, explanátion (*explànátion) we see stress reduction to avoid clash (Kager I989). Similarly, we find clash operating in phrases like àbstract árt where stress clash (*abstràct árt) is avoided by retracting the stress on the first word (Liberman \& Prince 1977). Turning now to meter, we find that 'dactylic' meter in English and Dutch studiously avoids stress clash, running [x..] and [x.] rather than [xx.] and [xx] as it does

[12] 'Relative strength' needs to be expressed more precisely in a grammar, and this can be done by relativizing NoClash to prosodic domains. A word-internal clash thus violates a higherranking constraint than a clash across words. This state of affairs can be shown to be directly related to the relative popularity of marginally different meters in the Classical Arabic tradition (Golston \& Riad 1997: 124). 
in Greek or Latin. The beginning of Charles Kingsley's Andromeda, for instance, is usually scanned with no stress clash, as follows:

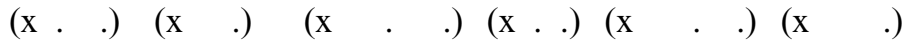

Over the sea, past Crete, on the Syrian shore to the southward,

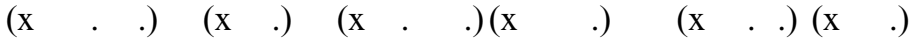

Dwells in the well-tilled lowland a dark-haired Aethiop people

We suspect that a clash-based meter is not serviceable in Dutch or English precisely because NoClash is ranked so high in these languages. Conversely, clash-based meter is serviceable in Greek and Latin because NoClasH is ranked so low in these languages.

\subsection{Lapse}

Trochaics violate NoLAPSE in the same way that dactylics violate NoClash. Cross-linguistically, there are two types of stress lapse: syllabic and moraic. Syllabic lapse involves adjacent stressless syllables, like the last two syllables of Cánada.

(53) Syllabic lapse

$$
\begin{aligned}
& \text { (x . .) } \\
& \begin{array}{lll}
\sigma & \sigma & \sigma
\end{array} \\
& \text { kæ . nə.də Cánada }
\end{aligned}
$$

Moraic lapse (Kager 1993) involves adjacent stressless moras, like the last two moras of sófa.

(54) Moraic lapse

$$
\begin{aligned}
& \text { (x . .) } \\
& \left(\begin{array}{ll}
\mu \mu & \mu
\end{array}\right) \\
& \text { sou.fə sófa }
\end{aligned}
$$

In a language with moraic trochees, every $\mathrm{H}+\mathrm{L}$ and $\mathrm{LL}+\mathrm{L}$ verse foot violates NoLAPSE.

(55) NoLAPSE 'Stressless moras/syllables must not be adjacent.'

This is the marked feature that distinguishes trochaic verse feet from other combinations of syllables.

(56) Trochaic $=_{\text {def }}$ violation of NoLAPSE

Indeed, if we look again at all possible verse feet of Greek meter, we see that only H.L and LL.L violate NoLAPSE. 


\begin{tabular}{|c|c|c|}
\hline & & NOLAPSE \\
\hline H.H & (xx) & \\
\hline H.L & (x.) & $\mathrm{T}$ \\
\hline H.LL & (xx.) & \\
\hline L.H & (.x) & \\
\hline L.L (. & or (x.) & \\
\hline L.LL & (.x.) & \\
\hline LL.H & (x.X) & \\
\hline LL.L & (x..) & $\mathrm{T}$ \\
\hline LL.LL & (x.x.) & \\
\hline
\end{tabular}

traditional term
spondee
trochee
dactyl
iamb
pyrrhic ${ }^{13}$
tribrach
anapest
tribrach
proceleusmatic

And these are just the verse feet one finds in Greek trochaic meter.

But we find in lyric far more HL than LLL. In traditional terms 'resolution' of the initial $\mathrm{H}$ to LL is avoided. The reason for this, we suspect, is that violation is minimal and lyric meter is stricter than dramatic meter. As we have already seen, HL violates NoLAPSE less than LL.L does: both have adjacent stressless moras but only the latter has adjacent stressless syllables.

The optimal trochee

\begin{tabular}{|lr||c|}
\hline & & NoLAPSE \\
\hline \hline H.H & M $\mu \mathrm{M} \mu$ & \\
\hline H.L & $\mathrm{M} \mu \mu$ & $\mu$ \\
\hline H.LL & $\mathrm{M} \mu \mathrm{M} \mu$ & \\
\hline L.H & $\mu \mathrm{M} \mu$ & \\
\hline L.L & $\mu \mu$ or M $\mu$ & \\
\hline L.LL & $\mu \mathrm{M} \mu$ & \\
\hline LL.H & $\mathrm{M} \mu \mathrm{M} \mu$ & \\
\hline LL.L & $\mathrm{M} \mu \mu$ & $\mu \sigma !$ \\
\hline LL.LL & $\mathrm{M} \mu \mathrm{M} \mu$ & \\
\hline
\end{tabular}

Again, Greek lyric meter is more precise than Greek dramatic meter, where both HL and LLL make acceptable trochees. This parallels the situation for dactylics exactly. In each case the more inclusive category is given by distinctive violation of a rhythmic constraint (NoLAPSE or NoClash), while

[13] The pyrrhic which occurs initially in ionics and anacreontics is problematic in that it allows two parses, as one or two metrical positions respectively. We assume that this type of ambiguity disqualifies the pyrrhic verse foot as a reliable lapse. For the same reason, presumably, LL is avoided as Aeolic base (cf. fn. Io and section 4.3). 
the metrical tightening is given by minimal violation of that same rhythmic constraint: HL avoids excessive violation of NoLAPSE just as HLL avoids excessive violation of NoClash. ${ }^{14}$

The definitional aspect of iambics and trochaics is that they contain exactly one constant moraic lapse. The notion 'constant' is key to the definition, as we can see when we evaluate trochaic metra in a tableau.

\section{Trochaics}

\begin{tabular}{|rc||c|c|}
\hline & & NoLAPSE & NOCLASH \\
\hline \hline ( $(\mathrm{HL} \mathrm{H} \sigma)$ & $\mathrm{M} \mu \mu \mathrm{M} \mu \sigma$ & $\mathrm{T}$ & \\
\hline$(\mathrm{HL} \mathrm{HL})$ & $\mathrm{M} \mu \mu \mathrm{M} \mu \mu$ & $\mathrm{T} * !$ & \\
\hline$(\mathrm{HL} \mathrm{HH})$ & $\mathrm{M} \mu \mu \mathrm{M} \mu \mathrm{M} \mu$ & $\mathrm{T}$ & $* !$ \\
\hline
\end{tabular}

All three candidates contain a moraic lapse, but the second candidate contains two. Thus, it will not do as the basic shape for a trochaic. The third candidate contains a constant clash in addition to the lapse, which is not desired for trochaic meter either. The optimal candidate has one variable position at the end. This is the reason why trochaics end in $\sigma$.

There is, however, a dimeter in which the medial $\sigma$ position shows up as a fixed L, namely the anacreontic: (LLHL)(HLHo). In this dimeter, the first trochaic is pyrrhic (LL). These facts are related. Consider a comparison of the two types.

Trochaics

\begin{tabular}{|cc||c|c|}
\hline & & NOLAPSE & NOCLASH \\
\hline \hline (HL H $\sigma)$ & $\mathrm{M} \mu \mu \mathrm{M} \sigma$ & $\mathrm{T}$ & \\
\hline (LL HL $)$ & $\mathrm{M} \mu \mathrm{M} \mu \mu$ & $\mathrm{T}$ & \\
\hline
\end{tabular}

Both types have the requisite lapse, just in different places, (HLHб) vs. (LLHL).

There is one more place where the required lapse could occur: across the two feet $(\sigma \mathrm{HLH})$. When a pair of feet has an internal NoLApse violation like this, traditional analysis calls it iambic (because it ends in LH). The natural class of NoLAPSE violators is thereby complete: 'trochaic' HLHo, 'anacreontic' LLHL, and 'iambic' $\sigma H L H$.

Turning now to the phonology of Greek speech, we note that moraic lapse is quite common and that there are no repair strategies for ameliorating it.

[14] This does not require gradient violation, which McCarthy (2003) has shown to be unnecessary and undesirable in OT. The violations here are categorical, one for each mora OR syllable that violates NoLAPSE. 
(6I) Lapse

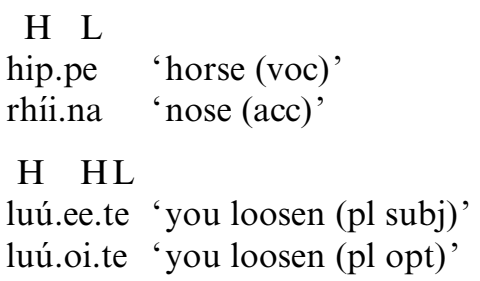

Again, we assume that the correlation is not accidental and that Greek makes distinctive metrical use of lapse precisely because it is allowed in Greek speech. Latin is similar. Although it avoids trapped light syllables with several quantitative adjustments (Mester I994), it does not single out HL or LLL feet in any way. Since it tolerates moraic lapse, we expect it to be able to use lapse distinctively like Greek, and it does. The lyric meters we have looked at here were used centuries later by Latin poets like Catullus and Horace.

We should not find meters like this in languages that avoid stress lapse, like Hawaiian (Elbert \& Pukui I979: I4) or Middle English (Prince I990). In Middle English one finds trochaic shortening (HL $>$ LL) to avoid moraic lapse and the meters we know of for Middle English make no distinctive use of moraic lapse (see e.g. Golston I998 on alliterative verse of the period).

\subsection{Exhaustivity}

The traditional notion of extrametricality suggests that there is more text than somehow fits easily into the meter. Given an adonean (HLL.Ho), the extra syllable of a reizianum ( $\sigma$ HLL.H $\sigma$ ) or the two extra syllables of pherecratean ( $\sigma \sigma$ HLL.Ho) come to look like they fall outside of the meter.

In order to model extrametricality formally, we use an OT constraint on prosodic layering. In the normal situation we find exhaustive layering: every syllable belongs to a foot, every foot belongs to a word, and so on (Selkirk I986). Since metrical positions in Greek are phonological feet (bimoraic), we need to consider the constraint that forces phonological feet to be parsed directly into words.

(62) Exhaustivity 'Every foot is directly dominated by a prosodic word.'

But Exhaustivity is violable in natural language (Ladd I986, Selkirk I995) and it is possible to have, e.g. a foot that is not directly dominated by a prosodic word but by a phonological phrase. This, we propose, is what extrametricality is in meter.

(63) Extrametricality $=_{\text {def }}$ violation of ExHAUSTIVITY 
There is metrical evidence that each syllable of the Aeolic base is a foot: the two-syllable Aeolic base is rarely LL in Sappho and Alcaeus and avoided altogether in later poetry (West 1982: 30). If the two syllables of a long Aeolic base constitute a single foot, it would tend to be LL; the fact that LL is systematically avoided suggests that $\sigma \sigma$ is two moraic trochees, not one. This is our reasoning behind defining the violation of ExHAUSTIVITY at this particular level of the prosodic hierarchy.

ExHAUSTIVITY is violable in Greek meter, we propose, because it is violable in Greek speech. Although strict layering is strongly preferred in every language, it is violated in Greek by proclitic articles (ho, hee, hoi, hai), prepositions (ek, in, eis, hoos), conjunctions (hoos, ei) and negatives (ou). These words are moraic trochees (phonological feet) but are not parsed into phonological words, as shown by their lack of pitch accent. Rather, they are adjoined directly to higher prosodic structure, the phonological phrase, in (minimal) violation of ExHAUSTIVITY (Selkirk I995).

Let us see what all of this is supposed to mean in the meters at hand. Consider the three simple dactylic cola discussed above.

(64) Dactylic dimeters

$\begin{array}{lrrr}\text { adonean } & \text { HLL.H } & & \text { DD } \\ \text { reizianum } & \sigma \text { HLL.H } & \sigma \text { DD } \\ \text { pherecratean } & \sigma \sigma \text { HLL.H } & \sigma \sigma \text { DD }\end{array}$

Reizianum is just an adonean with an extrametrical foot $(\sigma)$. That syllable will always form a moraic trochee (canonical or degenerate) on its own because it cannot form a foot with the following $\mathrm{H}$ syllable (the $\sigma$ is 'trapped', in the terminology of Mester 1994). In the pherecratean we find two such syllables in the base; they very rarely surface as LL (as a single moraic trochee) and almost always surface as $\mathrm{HL}, \mathrm{LH}$, or $\mathrm{HH}$ (as two moraic trochees).

Or compare the Alcmanic, Sapphic, and Alcaic strophes, discussed earlier.

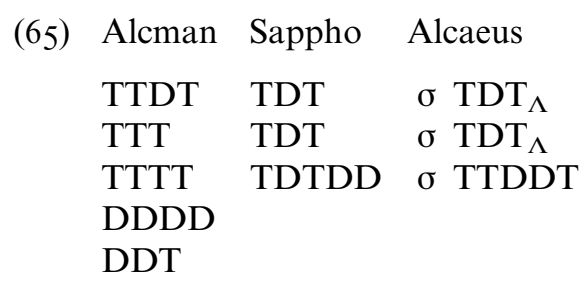

The affinity among these strophes is clear in the mixed use of trochaics and dactylics. What is different with Alcaeus is the extrametrical base at the beginning of each line (extrametricality) and the catalectic trochaics at the end of the first two lines. We have just dealt with the former as a violation of Exhaustivity. We turn now to the latter, which we shall treat as a violation of WORDBINARITY. 


\subsection{Binarity}

Standard trochaics and dactylics in the final line of the Alcaic strophe are matched with a catalectic trochaic in the first two lines. The final verse foot is just $\sigma$ rather than the expected Ho. If a verse foot (pair of metrical positions) corresponds to a phonological word (pair of moraic trochees), a catalectic verse foot must violate WorDBINARITY. This constraint is at work in e.g. Swedish and German, where nicknames are disyllabic: Swedish Janne, Kattis from Jan, Katarina, and German Hansi, Uni from Hans, Universität. A violation of WORDBINARITY makes a word unary. In meter, where binarity thrives, a distinctive violation of WORDBIN requires a verse foot (= prosodic word) to be non-branching.

(66) WordBIN 'Prosodic words branch binarily.'

When WordBIN is violated we get less text than expected, and so we formally represent the traditional notion of catalexis as intentional violation of WORDBIN.

\section{(67) Catalexis $=_{\text {def violation of WordBin }}$}

This neatly captures the traditional notion of catalexis as a truncated verse foot.

WordBIn is violable in Greek speech, where short prosodic words are common (monosyllabic géè 'earth'). Greek even tolerates monomoraic words like $t i$ ' what' and tó 'the' (both neuter nom/acc singular). Thus, we should not be surprised to find that catalexis is used throughout lyric meter in Greek, as well as in many other metrical systems. This seems to reflect the low rank of this constraint in most languages. Traditional Chinese meters, for instance, are typically based on lines that are five and seven syllables long, requiring non-binary verse feet (prosodic words on our account); this fits well with the fact that Chinese words are typically monosyllabic and thus frequently violate WoRDBIN.

Catalexis (or syncopation) usually targets the final element of a given domain, both in meter (Burling I966) and in phonology (Kiparsky I99I, Jacobs I994, Kager I995), but the final element of HLHo is $\sigma$, not H. So why is a catalectic trochaic not HLH? The reason is that catalectic trochaics always come at the end of a period, where phrase-final lengthening makes every syllable heavy. After phrase-final lengthening has applied there is no difference between HLo and HLH anyway and the issue is moot.

\subsection{Quantitative metathesis}

Traditional metrics uses anaclasis to reconcile what look like variants of the same basic line. We have seen this with anacreontic and ionic dimeter above and need to explain it here. We begin with the traditional notion. 
(68) Traditional conception of anaclasis

$(\mathrm{LLHL})(\mathrm{HLH} \sigma) \quad=$ anacreontic

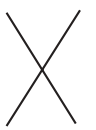

$(\mathrm{LLHH})(\mathrm{LLH} \sigma) \quad=$ ionic dimeter

The idea behind anaclasis is that two metrical positions ( $\mathrm{H}$ and $\mathrm{L}$ ) switch places, as indicated above: the real form is an anacreontic and the surface form is an ionic dimeter. We find derivational notions like this problematic in meter (and in phonology) and note that it does not help us in any case because our analysis requires an instance of stress lapse on the surface. We treat the ionic dimeter as a more marked anacreontic, one that violates both NoLAPSE and an additional constraint whose violation distinguishes ionics from the less marked anacreontics that surround it in a poem. If we focus on the surface feet and assume that there is a violation of NoLAPSE, we are forced to posit a misalignment of prosodic units (McCarthy \& Prince I993a). Normally, every foot begins crisply with a syllable.

(69) Alignment in anacreontic proper

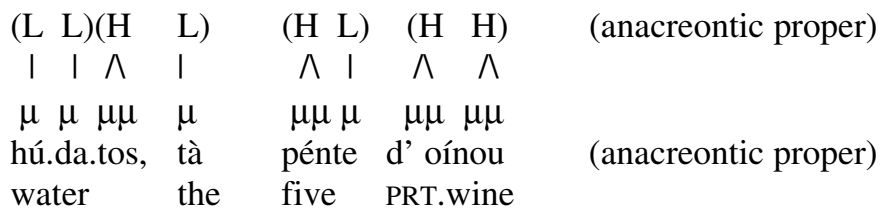

So-called anaclastic lines are those in which the two moras of a heavy syllable are spread across different feet.

(70) Quantity metathesis as misalignment

\begin{tabular}{|c|c|c|c|}
\hline$(\mathrm{L} \mathrm{L})(\mathrm{H}$ & L) & $(\mathrm{H} \mathrm{L})\left(\begin{array}{ll}H & \sigma\end{array}\right)$ & (anacreontic proper) \\
\hline $1 \mid \wedge$ & 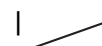 & $\neg 1 \wedge$ & \\
\hline$\mu \mu \mu \mu$ & $\mu \mu$ & $\mu \mu \mu \mu \mu \mu$ & \\
\hline ku.á.t $t^{\mathrm{h}}$ ous & hoos & a.nu.bris.toos & (ionic dimeter) \\
\hline ladles & so.that & not.proudly & \\
\hline
\end{tabular}

Here a heavy syllable of text (hoos) must be split between two metrical positions where its first mora goes to the second verse foot and its second mora goes to the third.

To account for quantity metathesis we need a constraint that aligns syllables with feet and that constraint must be violable. 
(7I) Align-L (Foot, $\sigma$ ) 'Every foot begins with a syllable.'

This constraint is respected throughout Greek meter and in the anacreontic proper but intentionally violated in the ionic dimeter, where a foot boundary cuts into a syllable boundary.

In natural language Align-L(FOOT, $\sigma$ ) is well established for stress systems (Hayes I995) but is violated in languages like Winnebago (Susman I943, Hale \& White Eagle I980, Halle \& Vergnaud I987), where heavy syllables are split between feet on a regular basis (see Hayes I995: 346ff. for an opposing view). The constraint is also well supported in meter, of course, but is violated in Japanese meters, for example, where $H$ syllables may occur spread across bimoraic feet. ${ }^{15}$ In Greek lyric meter we find anaclasis as a metrical device that structures lines. We define it in terms of its markedness as in (72).

(72) Anaclasis $={ }_{\text {def }}$ violation of Align-L(FOOT, $\left.\sigma\right)$

Thus when we say that the ionic dimeter is an anaclastic anacreontic, we mean that they are the same except for the misalignment of one syllable. This syllable is properly aligned in an anacreontic but misaligned in an ionic dimeter.

Align-L(FOOT, $\sigma$ ) is inviolate in Greek phonology, where footing always respects syllable boundaries. There was, however, a diachronic process of quantity metathesis, which took place after the split between Ionic and Attic Greek, resulting in cross-dialectal pairs like the following:

(73) Quantity metathesis

$\begin{array}{lll}\text { Ionic } & \text { Attic } & \\ \text { nee.ós } & \text { ne.óos } & \text { 'temple' } \\ \text { laa.ós } & \text { le.óos } & \text { 'people' } \\ \text { ba.si.lée.os } & \text { ba.si.lé.oos } & \text { 'king (gen sg)' } \\ \text { *ee.wa.loon } & \text { he.áa.loon } & \text { 'be captured' } \\ \text { te.t } \mathrm{t}^{\mathrm{h}} \text { nee.ó.tos } & \text { te. } \mathrm{t}^{\mathrm{h}} \text { ne.òo.tos 'dead, destroyed' } \\ \text { pó.lee.os } & \text { pó.le.oos } & \text { 'city (gen sg)' }\end{array}$

So this type of misalignment did take place in early Greek and casts some light on why violations of this constraint occur at all in Greek meter. ${ }^{16}$ We conjecture that Greek speakers who were familiar with different dialects like these would have had enough exposure to the historical reflexes of quantity metathesis to make quantity metathesis in meter a possibility, albeit a marginal one. It occurs at most once per strophe in lyric poetry and only in a

[I5] Japanese meters use four bimoraic feet (eight moras) per line. Only five or seven moras are filled with text; the rest go unfilled. In one type of recitation these empty moras are realized by carefully timed silence (Poser I990: 80).

[I6] We thank Mindaugas Strockis for reminding us of this process. 
few works of a few authors. In epic meter and dramatic dialogue it does not occur at all.

We can summarize all this markedness in a rough chart that compares the violability of each constraint in the phonology and meters of classical Greek.

(74) Markedness in meter and phonology

$\begin{array}{lllll} & \text { Phonology } & \begin{array}{l}\text { Lyric } \\ \text { authors }\end{array} & \text { Stichic authors } & \text { Violation once per ... } \\ \text { NoCLASH } & \text { weak } & \text { all } & \text { all epic } & \text { 2 metrical positions } \\ \text { NoLAPSE } & \text { weak } & \text { all } & \text { all dramatic } & 4 \text { metrical positions } \\ \text { WoRDBIN } & \text { stronger } & \text { some } & \text { some dramatic } & \text { line } \\ \text { EXHAUSTIVITY } & \text { stronger } & \text { some } & \text { few dramatic } & \text { line } \\ \text { ALIGN-FoOT } & \text { inviolate } & \text { few } & \text { none } & \text { strophe }\end{array}$

It appears that weak constraints which are freely violated in Greek phonology (NoClash, NoLAPSE) are those that are violated most in Greek meter, within a poem (many times per line), and across genres. Stronger constraints that are less commonly violated in the phonology (WordBin, EXHAustivity) are used more sparingly in Greek meter, within poems (at most once per line) and only in certain genres (lyric and dramatic, but not epic). Finally, the one constraint we have looked at that is never violated in attested Greek phonology (ALIGN-FoOT) is only rarely violated in poems (at most once per strophe, i.e. once per seven or so lines) by a few authors in a single genre.

\section{Previous accounts}

In this section we comment on other approaches to lyric meter. Our main complaint about them is that they are not linguistically based and thus are somewhat unrestrained in the primitives they use. In this paper we have tried to base all our units of analysis on structures one can find in Greek phonology. But even when judged merely as descriptive systems, traditional metrics exhibits serious shortcomings, a few of which we point out below.

Raven (1962) uses the choriamb as his basic unit of analysis, rather than the dactylics and trochaics we have argued for. We argue that the choriamb is unnecessary within the lyric tradition and useless outside of it (section 5.I). Korzeniewski (1968) and West (1982) propose theories whose basic units of analysis are large cola. We show that these cola are as unnecessary and as dispensable as choriambs (section 5.2).

\section{I A choriamb-based theory}

Raven (I962: 72) elevates the choriamb to an analytical principle for lyric meter:

[T] he aeolic does not run on any regular 'metron-scheme'. But in every aeolic line there is an essential nucleus consisting of a 'choriamb' $-\cup \cup-$ 
or an expansion of it; and this nucleus may be preceded and/or followed by other, more variable, syllables.

The idea is not uncommon (cf. Gerber 1970: I62). Its initial attraction is clear when one looks at what we have analyzed as lines with dactylic cores.

(75) Lyric meters that work as choriambs

\begin{tabular}{|c|c|c|}
\hline $\begin{array}{l}\text { adonean } \\
\text { reizianum } \\
\text { pherecratean }\end{array}$ & $\begin{array}{r}\sigma \\
\sigma \sigma\end{array}$ & $\begin{array}{l}\frac{\text { HLL.H } \sigma}{\text { HLL.H }} \sigma \\
\underline{\text { HLL.H }} \sigma\end{array}$ \\
\hline $\begin{array}{l}\text { aristophanean } \\
\text { hagesichorean } \\
\text { hipponactean }\end{array}$ & $\begin{array}{c}\sigma \\
\sigma \sigma\end{array}$ & $\begin{array}{l}\text { HLL.HLH } \sigma \\
\text { HLL.HLH } \\
\text { HLL.HLH }\end{array}$ \\
\hline $\begin{array}{l}\text { odrans } \\
\text { elesillean } \\
\text { lyconic }\end{array}$ & $\begin{array}{r}\sigma \\
\sigma \sigma\end{array}$ & 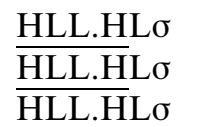 \\
\hline
\end{tabular}

These meters do seem to share a core stretch of HLLH, the traditional choriamb. Nevertheless, Raven's reduction is unsatisfying for a number of reasons.

First, taking the HLLH part out of the types above leaves us with a ragbag of remnants at the right edge, including leftover LH $\sigma$ (aristophanean, hagesichorean, hipponactean) and leftover Lo (dodrans, telesillean, glyconic). Neither of these pieces even has a name in Greek metrics, much less a secure place.

Second, the type 'choriamb' is not used in stichic (line-based) meter. There are no poems or plays whose lines run like the following:

\section{(76) Unattested line types}

*choriambic dimeter

*choriambic trimeter

HLLH.HLLH

$\mathrm{CC}$

*choriambic tetrameter

\section{HLLH.HLLH.HLLH CCC HLLH.HLLH.HLLH.HLLH CCCC}

For dactylics, on the other hand, we find entire epics (Iliad, Odyssey); for iambics and trochaics, we find all dialogue in tragedy and comedy. As far as we know, no one ever wrote a sustained work in choriambs. The closest thing to such lines is the eupolidean, used occasionally in comedy by Aristophanes (e.g. Clouds 518ff.). Raven (1962: 79) treats it as $\sigma \sigma \sigma \sigma+\mathrm{HLLH}+\sigma \sigma \mathrm{H} \sigma+$ HLH, hardly a convincing case for a meter based on HLLH.

Finally, choriambs are typologically bizarre. Iambs, trochees and dactylics can be interpreted as rising (LH), falling (HL, HLL) or neither (HH), but the choriamb combines HL with its mirror image LH. Also, iambics, trochaics and dactylics can be analyzed into two metrical positions each with at most two moras each (L.H, H.L, H.LL, H.H); the choriamb requires either three metrical positions with two moras (H.LL.H) or two metrical positions with three moras (HL.LH), both of which are anomalous elsewhere in Greek meter. 


\subsection{Colon-based theories}

Korzeniewski (I968) and West (I982) analyze lyric into cola larger than the dactylics and trochaics we have used. This eliminates the need for dactylics, trochaics, catalexis and extrametricality altogether and is thus radically distinct from what we have presented here.

The basic difference can be seen by comparing West's analysis in (37) above with ours in (45), though the differences may appear somewhat exaggerated. He notes, for instance, that many of the cola are simply other cola with an added initial base of $\sigma$ or $\sigma \sigma$ and that the anacreontic may be treated as an anaclastic version of the ionic dimeter. This reduces the real differences to the following meters:

(77) Major Aeolic meters

\begin{tabular}{|c|c|c|}
\hline & West 1982 & Our analysis \\
\hline adonean & HLLHo & DD \\
\hline trochaic & HLH $\sigma$ & $\mathrm{T}$ \\
\hline trochaic dimeter & HLHo.HLHo & $\mathrm{TT}$ \\
\hline lekythion & HLH $\sigma \mathrm{HL \sigma}$ & $\mathrm{TT}_{\Lambda}$ \\
\hline aristophanean & HLLHLHo & DT \\
\hline dodrans & HLLHLo & $\mathrm{DT}_{\Lambda}$ \\
\hline ithyphallic & HLH $\sigma \mathrm{H} \sigma$ & TD \\
\hline onic dimeter & LLHH.LLHo & $\mathrm{T}_{\mathrm{i}} \mathrm{T}_{\mathrm{i}}$ \\
\hline
\end{tabular}

Our analysis makes use of five analytic primes, all of them needed independently in phonology; three of these are also needed elsewhere in Greek meter (dactylics, trochaics, catalexis) and two are limited to lyric meter (extrametricality, quantity metathesis). West's analysis has more analytic primes (adonean, trochaic, lekythion, etc.) and thus less explanatory power, but this is not the major issue. The problem is that West's basic units have no life outside of meter or even outside of the lyric poets. The adonean is no more a part of Greek phonology than it is of Greek epic and dramatic meters. For this reason, West's analysis seems to us either preliminary or ad hoc.

It may help to compare the analyses in a less abstract manner, by looking at a single metrical type, the Alcaic strophe, which we analyze as in (78).

(78) Alcaic strophe according to us

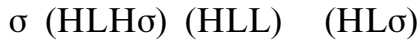
$\sigma \mathrm{TDT}_{\Lambda}$

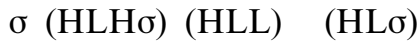
$\sigma \mathrm{TDT}_{\Lambda}$

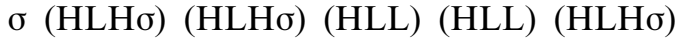
$\sigma$ TTDDT

Our analysis is not simple, as it makes use of trochaics, dactylics, extrametricality and catalexis all within the same strophe. So let us compare with 
the analyses of West (I982) and Korzeniewski (I968). For ease of comparison, we translate their notation into ours.

(79) Alcaic strophe according to West (I982:33)

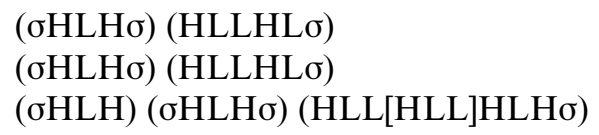

or

$$
\begin{aligned}
& \text { penthemimer + dodrans } \\
& \text { penthemimer + dodrans } \\
& \text { iambic }+ \text { penthemimer }+ \\
& \text { aristophanean with a } \\
& \text { dactylic expansion [HLL] }
\end{aligned}
$$

iambic + iambic + hagesichorean with a dactylic expansion [HLL]

West's approach has a number of shortcomings. First, the parallel with the Sapphic and Alcaic strophes is blurred. For the analysis of the Sapphic stanza, West uses the following cola: initial catalectic iambic (ØHLH) and hagesichorean for the first two lines, and for the last line initial catalectic iambic and then either unexpanded hagesichorean + adonean, or, alternatively, telesillean $(\sigma H L L H L \sigma)+$ reizianum $(\sigma H L L H \sigma)$. On this analysis the Alcaic strophe and the Sapphic stanza share little or nothing. On our analysis the basic units are the same: Alcaeus only tinkers with extrametricality and catalexis, and the metrical similarities between the poets are expressed right in the analysis.

Second, the cola that West uses are, with the exception of the iambic, all quite large, crying out for further analysis. Our analysis has catalexis and extrametricality in the same line, but does manage to break up the long string of symbols into manageable and familiar units.

Third, West admits two quite different analyses for the final line of both the Alcaic and the Sapphic stanzas. This signals a major weakness of the descriptive apparatus, in that it provides too many descriptions for the same object. These undesirable properties are also found in Korzeniewski's work.

(80) Alcaic strophe according to Korzeniewski (I968: I29)

$\begin{array}{ll}(\sigma \mathrm{HLH})(\sigma \mathrm{HLLHL} \sigma) & \begin{array}{c}\text { iambic }+ \text { glyconic without } \\ \text { initial position }{ }^{17}\end{array} \\ (\sigma \mathrm{HLH})(\sigma \mathrm{HLLHL}) & \text { iambic }+ \text { glyconic without } \\ & \text { initial position } \\ (\sigma \mathrm{HLH})(\sigma \mathrm{HLH})(\sigma \mathrm{HLL}[\mathrm{HLL}] \mathrm{HLH} \sigma) & \begin{array}{l}\text { iambic }+ \text { iambic }+ \\ \text { hipponactean } \text { without }^{18} \\ \text { initial position, }{ }^{18} \text { but with a } \\ \text { dactylic expansion }[\mathrm{HLL}]\end{array}\end{array}$

[I7] Korzeniewski does not use the term 'dodrans'.

[18] Korzeniewski does not use the term 'hagesichorean'. 
There is something ad hoc about this analysis, too, and it fails to bring out much except that the strophe is complicated and looks less like those of Sappho than one would expect. More importantly, it is ad hoc in using units that are not encountered elsewhere in the phonology or meter of Greek.

\section{Conclusion}

There are many distinct types of Greek lyric meter. They cannot all be phonologically or metrically unmarked, so it is worth comparing them in terms of markedness. When we look at actual Greek phonology and parse the poems into moraic trochees, we find that the meters involve perfectly regular violations of NoClash (dactylic) and NoLAPSE (trochaic and iambic) and, less often, of Exhaustivity (extrametricality), Binarity (catalexis) and Alignment (quantity metathesis/anaclasis). For the most part, what distinguishes one meter from another is how the clashes and lapses are distributed and whether or not there is more text than expected (extrametricality) or less (catalexis).

It has been proposed that markedness is what matters in phonology and morphology and it now begins to look like markedness plays a similar role in distinguishing different types of meter within a metrical tradition. Just as prosodic layering, binarity and alignment can be violated for artistic effect, it seems that rhythm can be violated too. Greek lyric meter is then a carefully orchestrated way of toying with the expectations of metrically sophisticated listeners. Dactylics and trochaics play with eurhythmy; catalexis and extrametricality play with layering and binarity; and quantity metathesis plays with alignment.

\section{REFERENCES}

Allen, W. Sidney (1973). Accent and rhythm. Prosodic features of Latin and Greek: a study in theory and reconstruction. Cambridge: Cambridge University Press.

Allen, W. Sidney (1987). Vox Graeca: a guide to the pronunciation of Classical Greek (3rd edn.). Cambridge: Cambridge University Press.

Brown, Christopher G. (1997). Iambos. In Gerber, Douglas E. (ed.) (1997). A companion to the Greek lyric poets. Leiden: Koninklijke Brill. II-88.

Burling, Robbins (1966). The metrics of children's verse: a cross-linguistic study. American Anthropologist 68. I4I8-I44I.

Dale, A. M. (1950). The metrical units of Greek lyric verse. Classical Quarterly XLIV. I38-I48.

Dale, A. M. (1968). The lyric metres of Greek drama. Cambridge: Cambridge University Press.

Davison, John A. (1968). From Archilochus to Pindar: papers on Greek literature of the archaic period. London: Macmillan and Co.

Elbert, Samuel \& Pukui, Mary Kawena (1979). Hawaiian grammar. Honolulu: University Press of Hawaii.

Farnell, George S. (I89I). Greek lyric poetry: a complete selection of the surviving passages from the Greek song-writers. London: Longmans, Green, and Co.

Gerber, Douglas E. (1970). Euterpe: an anthology of early Greek lyric, elegiac, and iambic poetry. Amsterdam: Adolf M. Hakkert.

Golston, Chris (1989). Floating H (and L*) tones in Ancient Greek. Proceedings of the Arizona Phonology Conference 3 (Coyote Papers). Tucson, AZ: University of Arizona. 
Golston, Chris (199I). Both lexicons. Ph.D. dissertation, UCLA.

Golston, Chris (1995). Syntax outranks phonology: evidence from Ancient Greek. Phonology $\mathbf{2}$. 343-368.

Golston, Chris (1996). Direct OT: representation as pure markedness. Language 72. 713-748.

Golston, Chris (1998). Constraint-based metrics. Natural Language \& Linguistic Theory I6. 719-770.

Golston, Chris \& Riad, Tomas (1997). The phonology of Classical Arabic meter. Linguistics 35. III-I32.

Golston, Chris \& Riad, Tomas (2000). The phonology of Classical Greek meter. Linguistics $\mathbf{3 8 .}$ 99-167.

Hale, Kenneth \& White Eagle, Josie (1980). A preliminary metrical account of Winnebago accent. International Journal of American Linguistics 46. II7-I32.

Halle, Morris \& Vergnaud, Jean-Roger (1987). An essay on stress. Cambridge, MA: MIT Press.

Halporn, James W., Ostwald, Martin \& Rosenmeyer, Thomas G. (I980). The meters of Greek and Latin poetry (revised edition). Norman, OK: University of Oklahoma Press.

Hayes, Bruce (1989). The prosodic hierarchy in meter. In Kiparsky, Paul \& Youmans, Gilbert (eds.), Rhythm and meter. San Diego, CA: Academic Press. 20I-260.

Hayes, Bruce (1995). Metrical stress theory: principles and case studies. Chicago: The University of Chicago Press.

Hermann, Johann G. (I816). Elementa Doctrinae Metricae. Leipzig.

Jacobs, Haike (1994). Catalexis and stress in Romance. In Mazzola, Michael L. (ed.), Issues and theory in Romance linguistics. Washington, DC: Georgetown University Press. 49-56.

Kager, René (1989). A metrical theory of stress and destressing in English and Dutch (Linguistic Models I4). Dordrecht: Foris.

Kager, René (1993). Alternatives to the iambic-trochaic law. Natural Language \& Linguistic Theory II. 38I-432.

Kager, René (1995). Consequences of catalexis. In van der Hulst, Harry \& van de Weijer, Jeroen (eds.), Leiden in last. The Hague: Holland Academic Graphics. 269-298.

Kiparsky, Paul (199I). Catalexis. Ms., Stanford University \& Wissenschaftskolleg zu Berlin.

Korzeniewski, Dietmar (1968). Griechische Metrik. Darmstadt: Wissenschaftliche Buchgesellschaft.

Ladd, D. Robert (1986). Intonational phrasing: the case for recursive prosodic structure. Phonology Yearbook 3. 3II-340.

Liberman, Mark \& Prince, Alan (1977). On stress and linguistic rhythm. Linguistic Inquiry 8. 249-336.

Maas, Paul (1962). Greek metre (translated by Hugh Lloyd-Jones). Oxford: Clarendon Press.

McCarthy, John (2003). OT constraints are categorical. Phonology 20. 75-138.

McCarthy, John \& Prince, Alan (1993a). Generalized alignment. In Booij, Geert \& van Marle, Jaap (eds.), Yearbook of morphology 1993. Dordrecht: Kluwer Academic Publishers. 79-I53.

McCarthy, John \& Prince, Alan (I993b). Prosodic morphology I. Ms., University of Massachusetts at Amherst \& Rutgers University.

McCarthy, John \& Prince, Alan (1995). Faithfulness and reduplicative identity. In Beckman, Jill, Walsh Dickey, Laura \& Urbanczyk, Suzanne (eds.), Papers in Optimality Theory (University of Massachusetts Occasional Papers in Linguistics I8). 249-384.

Mester, Armin (1994). The quantitative trochee in Latin. Natural Language \& Linguistic Theory I2. I-6I.

Nespor, Marina \& Vogel, Irene (1986). Prosodic phonology. Dordrecht: Foris.

Nespor, Marina \& Vogel, Irene (I989). On clashes and lapses. Phonology 6. 69-II6.

Noyer, Rolf (1997). Attic Greek accentuation. In Roca, Iggy (ed.), Derivations and constraints in phonology. Oxford: Clarendon Press. 50I-528.

Page, Denys L. (1955). Sappho and Alcaeus: an introduction to the study of ancient Lesbian poetry. Oxford: Oxford University Press.

Poser, William J. (1990). Evidence for foot structure in Japanese. Language 66. 79-I05.

Prince, Alan (I990). Quantitative consequences of rhythmic organization (Parasession on the Syllable in Phonetics and Phonology). Chicago Linguistic Society 26. 355-398.

Prince, Alan \& Smolensky, Paul (1993). Optimality Theory: constraint interaction in generative grammar. Ms., Rutgers University \& University of Colorado at Boulder.

Raven, David S. (1962). Greek metre. London: Faber \& Faber. 
Selkirk, Elizabeth O. (1984). Phonology and syntax: the relation between sound and structure. Cambridge, MA: MIT Press.

Selkirk, Elizabeth O. (1986). On derived domains in sentence phonology. Phonology 3. 37I-405.

Selkirk, Elizabeth O. (I995). The prosodic status of function words. In Beckman, Jill, Walsh Dickey, Laura \& Urbanczyk, Suzanne (eds.), Papers in Optimality Theory. Amherst, MA: University of Massachusetts, GLSA.

Snell, Bruno (1962). Griechische Metrik (3rd edn.). Göttingen: Vandenhoeck \& Ruprecht.

Susman, Amelia (1943). The accentual system of Winnebago. Ph.D. dissertation, Columbia University, New York.

West, Martin L. (1982). Greek metre. Oxford: Oxford University Press.

West, Martin L. (ed.) (1989). Iambi et elegi Graeci (vols. I \& II, 2nd edn.). Oxford: Oxford University Press.

West, Martin L. (1993). Greek lyric poetry: the poems and fragments of the Greek iambic, elegiac, and melic poets (excluding Pindar and Bacchylides) down to 450 B.C. Oxford: Clarendon Press.

Authors'addresses: (Golston)

Department of Linguistics, California State University Fresno,

PB 92, Fresno, CA 93740-80oI, U.S.A.

Email: chrisg@csufresno.edu

(Riad)

Department of Scandinavian Languages, Stockholm University,

SE-Io6 9I Stockholm, Sweden.

Email:tomas.riad@nordiska.su.se 